\title{
Grassland biomass dynamics along an altitudinal gradient in the Pampa
}

\author{
CAROLINA A. PÉREZ AND JORGE L. FRANGI
}

Authors are plant ecologists of the Laboratorio de Investigación de Sistemas Ecológicos y Ambientales (LISEA), Universidad Nacional de La Plata, CC 31, 1900 La Plata, Argentina. E-mail: lisea@ceres.agro.unlp.edu.ar

\begin{abstract}
Above and below-ground biomass and necromass dynamics were assessed for 3 grassland sites located at 550, 850, and 1,025 $m$ elevation in Sierra de la Ventana range $\left(38^{\circ} 1^{\prime} \mathrm{S} 62^{\circ} 2^{\prime} \mathrm{W}\right)$ in Argentina. The objective was to determine if differences existed in dry matter structure, mycorrhizae infection, net primary productivity (NPP) partitioning to aboveground and belowground tissues, senescence and litter fall, and seasonal patterns of dry matter fluxes with altitude. Soil properties, water budgets and temperature at the sites were also assessed. Biomass plus necromass (without litter) was $1,184 \pm 41,1,208 \pm 70$, and $1,507 \pm 63$ $\mathrm{gDM} \mathrm{m}^{-2}$ for the lower, intermediate and upper sites, respectively. The below: aboveground biomass ratio increased with elevation. Total NPP was $1,131,1,280$, and $1,157 \mathrm{gDM} \mathrm{m}^{-2}$ year $^{-1}$, respectively, for the 3 grassland sites. belowground allocation of net productivity increased with altitude. Both mass and proportion of thin roots increased with elevation, and so did mycorrhizae infection. The aboveground and belowground turnover rates decreased with altitude, but rates were faster for aboveground tissues. We found different temporal patterns in productivity, senescence and disappearance among grassland sites despite similar total NPP. Water holding capacity of soils and temperature were important factors related to several of the observed trends in structure and function. Differences in grassland structure and fluxes are discussed as related to soils and local climate at each site.
\end{abstract}

Key Words: aboveground, belowground, litter, phytomass, productivity, roots

Natural grasslands dominate the landscape of the Sierras Australes (Buenos Aires, Argentina). The grass genera with more native species in the area are Stipa and Piptochaetium; other important species because of their abundance include Briza, Sorghastrum and Festuca. These hills (spanish sierras) are a gondwanic folding system extending NE to SW, $170 \mathrm{~km}$ in length x $65 \mathrm{~km}$ maximum width. The highest point in the Pampas is

Research was funded in part by Comisión de Investigaciones Científicas de la Provincia de Buenos Aires, Universidad Nacional de La Plata and the Cooperadora Parque E Tornquist, and developed in cooperation with the International Institute of Tropical Forestry-USDA Forest Service, Puerto Rico. Authors thank Marcelo Arturi, Martha Cabello, Ricardo Varela and Walter Canónica for statistical, mycorrhizal, geological and field assistance, respectively. We also thank Marcelo Barrera, Richard Joost, Joe Trlica and an anonymous reviewer whose comments helped to improve earlier versions.

Manuscript Accepted 17 Jan. 2000.

\section{Resumen}

Se evaluó la dinámica de la biomasa y necromasa, aéreas y subterráneas, de tres sitios de pastizal ubicados a 550, 850, y $1,025 \mathrm{~m}$ de elevación en la Sierra de la Ventana $\left(38^{\circ} 1\right.$ 'S $\left.62^{\circ} 2^{\prime} \mathrm{O}\right)$, Argentina. El objetivo fue determinar si existían diferencias en la estructura de la materia seca, la micorrización, la asignación de la producción primaria neta (NPP) a tejidos aéreos y subterráneos, la senescencia y caída al mantillo, y los patrones de los flujos de materia seca con la altitud. También se consideraron las propiedades del suelo, los balances de agua y la temperatura de cada sitio. La biomasa más la necromasa ( $\sin$ broza) fue de 1,184 $\pm 41,1,208 \pm 70$ y $1,507 \pm 63 \mathrm{gMS} \mathrm{m}^{-2}$ para los sitios inferior, intermedio y superior, respectivamente. El cociente biomasa subterránea:aérea se incrementó con la elevación. La NPP total fue $1,131,1,280$ y $1,157 \mathrm{gMS} \mathrm{m}^{-2}$ año $^{-1}$, respectivamente, para los tres sitios de pastizal. La asignación subterránea de la productividad primaria neta se incrementó con la altitud. La masa y la proporción de raíces finas, como también el porcentaje de micorrización, aumentaron con la elevación. Las tasas de renovación aérea y subterránea decrecieron con el aumento de la altitud, pero las tasas fueron más rápidas para los tejidos aéreos. Nosotros encontramos distintos patrones temporales en la productividad, senescencia y desaparición entre pastizales a pesar de su similar NPP. La capacidad de retención de agua del suelo y la temperatura fueron importantes factores relacionados a varias de las tendencias observadas en la estructura y funcionamiento de los pastizales. Las diferencias en la estructura y los flujos de los pastizales son comentadas en relación a los suelos y clima local de cada sitio.

peak Tres Picos (1,243 m elevation) (Harrington 1947, Suero 1972). The macroclimate at this area has been described elsewhere (Burgos 1968, Cappanini et al. 1971, Frangi and Bottino 1995). According to Thornthwaite (1948) the climate is C2 B'2 r a' -humid-subhumid, mesothermal, with a small to null water deficit, and a summer thermal concentration $<48 \%$. Because of the low elevation of the hills, and being perpendicular to the atmosphere general circulation, they are not an effective condenser of atmospheric humidity but are effective in temperature reduction. Precipitation diminishes from NE to SW. Sierra de la Ventana (249 $\mathrm{m}$ asl), the nearest town to the study area, has an annual-long term mean temperature of $14.5^{\circ} \mathrm{C}$ and $809 \mathrm{~mm}$ precipitation. In the Pampas, the interannual variation of rains is ca. $\pm 50 \%$ of the mean (Vervoorst 1967, Cappaninni et al. 1971).

The local geology is characterized by siliciclastic sedimentites of the Ventana Group, Lower Devonic age, containing fossils of Brachyopoda (Andreis et al. 1989, Von Gosen et al.1990). They 
mostly consist of cross-bedded quartzites and sandstones, with grain-size diminishing upward cycle. Group thickness is about $1,400 \mathrm{~m}$. Wide and shallow platforms and littoral zones constituted the paleoenvironment. Rocks were deformed by folding and internal faulting. The resulting sierras profile was asymmetric, with the eastern flank more extended and formed by steps motivated in the structural repetition by folding of more resistant lithological levels. The soils are lithic Hapludols, typic and lithic Argiudols and lithic Haplumbrets developed on quaternary loessoid sediments sometimes mixed with fragments of base rock or intercalated $\mathrm{CaCO}_{3}$ rock layers (Cappanini et al. 1971, Vargas Gil and Scoppa 1973, Frangi et al. 1980a, 1980b, Pérez 1996).

Grassland communities have been linked to differences in biotope and mesoclimate (Frangi and Bottino 1995, Kristensen and Frangi 1995). The greatest dissimilarity in local climates was between lowland and mountain grassland sites. The former are warm, anisothermic with higher diurnal evaporative capacity. They are covered by medium-sized feather grasses (Stipa and Piptochaetium species) in the piedmont and medium-sized tussocks of Stipa caudata Trinius or S. ambigua Spegazzini and $S$. caudata Trinius grasslands in deep soils of the valley bottoms ${ }^{1}$. Steep SW slopes differ markedly in local climate and grass flora compared with gentle slopes (Frangi and Bottino 1995, Kristensen and Frangi 1995). Steep SW slopes are cold, isothermic, and very humid, receive low solar radiation during most of the year and are covered by Festuca pampeana Spegazzini tussock grasslands.

The NE and SW gentle slopes are covered by Sorghastrum pellitum (Hackel) Parodi and Stipa filiculmis Delile short grassland. They show intermediate conditions between the upper and lowland sites. The thermal gradient supported the existence of a montane bioclimatic belt above $750 \mathrm{~m}$.

Mountain summits and high ridges are covered with short grasses and cushion plants. Fine textured soils give rise to high sierra meadows with Briza subaristata Lamarck, B. brizoides (Lamarck) O. Kuntze and Festuca ventanicola Spegazzini in concave to flat more humid sites, with Sorghastrum pellitum and Stipa filiculmis short grassland on upper slopes. Stony soils are covered by Grindelia chiloensis Cabrera an evergreen dwarf 1970). shrub. Climatic conditions are more extreme; they are colder and windy with the highest evaporative air capacity (Piche method) that is reduced in the winter because of clouds and mist.

Vegetation differs in physiognomy, species composition, and phytogeographic relationships among plant species (de la Sota 1967, Frangi and Bottino 1995). Biomass structure changes as well with elevation, slope and aspect (Barrera and Frangi 1994). aboveground biomass decreases and belowground biomass increases with altitude. aboveground net primary productivity (ANPP) has only been measured in low altitude grassland sites (Frangi et al. 1980a, 1980b).

Mountain grasslands are used as grazing lands (Ricci 1992). Overgrazing encourages bush encroachment (Barrera 1991, Barrera and Frangi 1996). Non-disturbed grasslands are important in erosion control and water quality of tributaries of the Sauce Grande river, a source of consumption water for the city of Bahía Blanca (Dascanio and Bianchi pers. com.). Exotic tree plantations are assumed by local people to protect steep slopes but symptoms of overland erosion under forest canopy are common (Frangi and Bottino 1995, Barrera and Frangi 1996).

The compositional, physiognomical and structural changes in biomass with topography, soil and local climate caused us to select an altitudinal gradient with a more limited complexity to answer the following questions: Are differences in dry matter structure correlated with net primary productivity (NPP) changes or only with partitioning among above- and belowground tissues? Do seasonal patterns in dry matter fluxes change along the altitudinal gradient? The hypotheses were: (1) Above- and belowground community biomass structure changed with elevation to reflect adaptations to improve available resource absorption; (2) NPP diminished with altitude because of less favorable local climate and soil conditions; (3) NPP allocation changed with elevation toward a greater proportion of roots at higher elevations; and, (4) Community differences in temporal patterns of dry matter fluxes indicated differences in plant strategies to changes in temperature and water availability along the elevational gradient.

The objectives were to determine the biomass and necromass structure including root sizes and mycorrhizae infection, net primary productivity partitioning to above- and belowground tissues, senescence and litter fall, and seasonal patterns of above- and belowground net productivi- ty, senescence and disappearance at 3 grassland sites located at 550, 850, and $1,025 \mathrm{~m}$ asl. Soil properties, water budgets, and temperature at these sites were also determined.

\section{Methods}

\section{Study sites}

The 3 sites were located on an eastern secondary divide at peak El Destierro I $\left(38^{\circ} 1^{\prime} \mathrm{S} 62^{\circ} 2^{\prime} \mathrm{W}\right)$, Ernesto Tornquist Nature Reserve. Slope was about 3\% at all sites. Plant communities (Frangi and Bottino 1995) were described as short grassland with Piptochaetium hackelii (Arechavaleta) Parodi and P. napostaense (Spegazzini) Hackel, with Briza subarista ta Lamarck dominating the low site (550 m). Short grassland with Sorghastrum pel litum (Hackel) Parodi and Stipa filiculmis Delile dominate the intermediate and high sites $(850$ and $1,025 \mathrm{~m})$. In this paper we refer to the sites as lower (LS) $550 \mathrm{~m}$ elevation, intermediate (IS) $850 \mathrm{~m}$ elevation, and upper (US) 1,025 m elevation.

\section{Soils}

Six to 9 soil cores $(0-20 \mathrm{~cm}$ depth) were obtained at random from a 0.5 ha area, in spring, fall and winter, from each site. These samples were immediately cleaned of roots and air-dried. A mixed composite soil sample for each site and date was prepared for physico-chemical analysis $(n=3$ per site). Traditional methods were employed for texture using a sieving machine and densimeter (Duchaufour 1970). Soil $\mathrm{pH}$ was determined in a $1: 1$ (soil:water) paste using a $\mathrm{pH}$ meter with a combination electrode. Total soil nitrogen $(\mathrm{N})$ and carbon $(\mathrm{C})$ were determined using the CNS LECO 2000 procedure (Tabatabai and Bremner 1991). Available P was analyzed with the Bray \& Kurtz \#1 method (Page 1982). The cation exchange capacity (CEC) was assessed using $1 \mathrm{~N}$ neutral ammonium acetate extraction (Page 1982). Exchangeable $\mathrm{Ca}, \mathrm{Mg}$, and $\mathrm{Na}$ were determined using $1 \mathrm{~N} \mathrm{KCl}$ extraction method and exchangeable $\mathrm{K}$ with Olsen EDTA procedure (Hunter 1982). Additionally, during the spring sampling, apparent density (AD) was estimated for 3 soil cores of known volume $(6.5 \mathrm{~cm}$ diam. $x 10 \mathrm{~cm}$ height) at $0-10$ and $10-20 \mathrm{~cm}$ depth per site and dried at $70^{\circ} \mathrm{C}$ to constant weight. An average apparent density for $0-20 \mathrm{~cm}$ soil depth was calculated for each site $(n=3)$ discarding weight of pebbles. Soils were classified according to the Soil Survey Staff (1992). 


\section{Water budgets}

Thornthwaite's (Thornthwaite and Mather 1957) water budgets were calculated for each site using a computer program. Water retention maximum capacity (WRM) at each site was estimated according to:

WRM $(\mathrm{mm})=(0.023 \mathrm{x}$ sand fraction $+0.25 \times$ silt $+0.61 \times$ clay $) \times$ AD $(\mathrm{g}$ $\mathrm{cm}^{-3}$ ) X depth (cm) x 10.

Monthly temperatures were estimated with data from the Sierra de la Ventana weather station (SMN 1981), altitudinal thermal gradients for each season (Kristensen and Frangi 1995) and site elevation. Weekly precipitation during the study period was measured with 1 standard US Weather Bureau type rain gauge per site.

\section{Biomass and necromass}

We used the following definitions: biomass was dry weight of live plant material; necromass was dead plant mass (standing dead, litter, and dead roots); aboveground dry matter was aboveground biomass plus standing dead; belowground dry matter was the sum of live and dead roots and, total dry matter was biomass plus necromass.

Sampling was done in 0.5 ha grazing exclosures, at 9 dates between July 1988 and July 1989. A stratified randomized design was used for sampling above- and belowground live and dead mass compartments. The aboveground dry matter was estimated by the harvest method (Milner and Hughes 1970). At each grassland site and on each date we collected ten, $0.25 \times 1$ $m$ pseudoreplicates (according to Hurlbert 1984). Plant matter and litter were collected in separate bags. To avoid resampling a plot, we put a stake in each clipped quadrat. Plant matter was hand-separated into categories: green grasses, green dicotyledonous herbs, standing dead material, and reproductive tissue.

The belowground dry matter in $0-10$ and $10-20 \mathrm{~cm}$ soil depth was estimated using a $6.5 \mathrm{~cm}$ diam. $\mathrm{x} 10 \mathrm{~cm}$ height soil core. On each date and site we extracted 10 cores from each soil depth at each aboveground harvest unit. Cores were processed by wet sieving over a $1-\mathrm{mm}^{2}$ mesh screen (Böhm 1979). Collected roots were washed free of soil, visually classified, and separated with tweezers into live (soft, translucent, white to brownish) or dead (brittle, opaque, and grayish) according to Böhm (1979) and McClaugherty et al. (1982) and subdivided according to diameter as thin $(<1 \mathrm{~mm})$ or thick $(>1 \mathrm{~mm})$ roots. Plastic bags containing sampled plants, litter, or soils were stored in a freezer $\left(-12^{\circ} \mathrm{C}\right)$ until they were separated, classified and dried to constant weight at $70^{\circ} \mathrm{C}$.

\section{Mycorrhizae}

We estimated arbuscular (A-) mycorrhizae fungal infection of roots in each grassland in December 1988. Six soil samples were taken from each soil depth. Roots were extracted, clarified with $\mathrm{KOH}$ $(7.5 \%)$ at $90^{\circ} \mathrm{C}$ for 20 -minutes and stained employing the procedure of Phillips and Hayman (1970). Infection was measured with a line-intercept method under a $40 \mathrm{X}$ stereomicroscope (Giovannetti and Mosse 1980). A-mycorrhizal spores were extracted with the wet-sieving and decant technique (Gerdemann and Nicolson 1963) and counted under a 10X stereomicroscope.

\section{Fluxes}

For aboveground net primary products (ANPP), senescence, litterfall, and disappearance calculations we used the sum of differences between live and dead compartments (Frangi et al. 1980 a). Likewise we modified the equations to calculate belowground fluxes (Table 1). We used only the significant differences (Student $t$, $\mathrm{P}<0.05)$ between the extremes of intervals with increasing or decreasing values trends of each compartment.

Total net primary products (NPP) was the sum of ANPP and belowground net primary products (BNPP). Aboveground and belowground turnover rates were calculated as the ratio between productivity and the annual mean of biomass of above and belowground compartments, respectively (Frissel 1981). Dry matter turnover rates were calculated employing the equivalent dry matter values.

Table 1. Formula to calculate aboveground and belowground dry matter fluxes, net primary productivity (ANPP = aboveground; BNPP = belowground $)$, senescence $(\mathrm{M})$, litterfall $(\mathrm{C})$ and disappearance $(D)$.

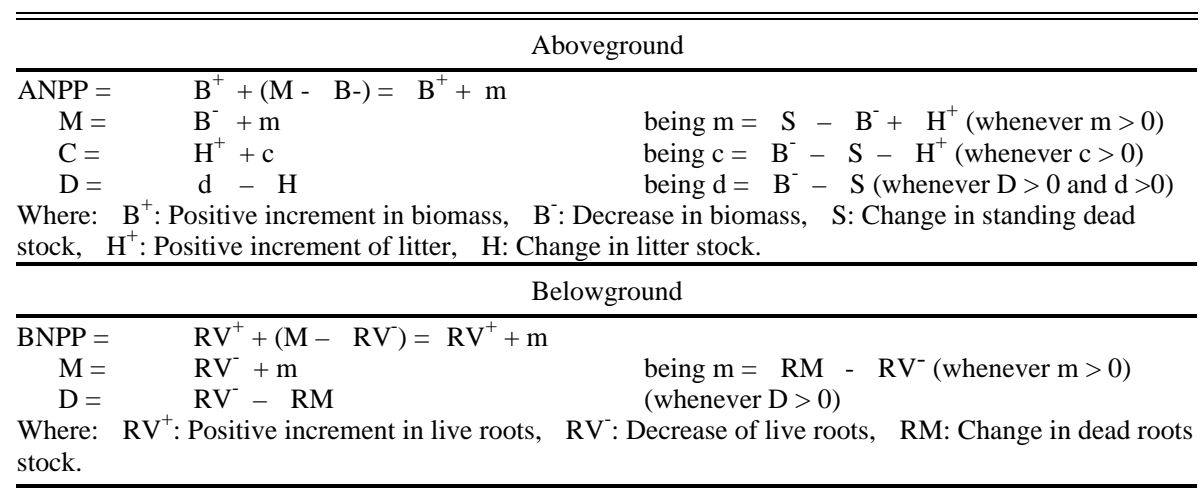

\section{Statistics}

The differences in soil parameters among sites were compared with a oneway ANOVA. The plant compartment differences among sites and dates were evaluated using a repeated measure ANOVA. Previously we corroborated the variance homogeneity. To compare percentages of aboveground and belowground biomass compartments with total biomass we transformed the data to arc $\sin \left(\%^{1 / 2}\right)$. We employed the F-test to determine significant differences between dates and sites and the studentized rank test of Tukey (P $<0.05$ ) for mean comparisons (Sokal and Rohlf 1969). Multiple regression analysis among plant mass compartments or ratios and independent variables. This analysis was performed with the pooled data of the 3 sites. The partial correlation of this variable was calculated after fitting other independent variables into an equation. When a non-significant partial correlation was found, it was interpreted that the other independent variables accounted for most of the differences among sites.

\section{Results}

\section{Soils and water budget}

Soils at all sites were classified as Lithic Hapludolls, notwithstanding a lower base saturation of some samples that indicated at intermediate site (IS) and upper site (US) there were Lithic Haplumbrepts also present. The texture was clay loam to loam at lower site (LS), loam at IS and between LS and US (Table 2). The organic carbon values were very high and the $\mathrm{C}: \mathrm{N}$ ratios are similar and common to Pampa grassland soils. Soil $\mathrm{pH}$ decreased with elevation and was moderately acid at was applied to explain relationships sandy loam at US. Clay decreased by $50 \%$ 
LS and moderately to very acid at both other sites. The CEC was similar at all sites, but its variation increased with elevation. Base saturation was high at low altitude and moderate at high elevation (Table 2). A traditional fertility data interpretation indicated that these soils were very well supplied in total $\mathrm{N}$, moderately supplied in $\mathrm{P}$, and adequately supplied in exchangeable K. Exchangeable $\mathrm{Ca}$ was well supplied at LS, but its CEC-saturation was significantly lower at IS and US. Magnesium was high at all sites and showed the same trend as Ca.

Low values of apparent soil bulk density can be related to the high organic matter content, with inter-site differences attributable to texture changes and also to a greater fraction of discarded pebbles at IS and US (Table 2).

Annual precipitation (P) increased with elevation, with 745,786 , and $828 \mathrm{~mm}$ at the LS, IS, and US, respectively. Days with rains were 29,30 , and 25 at LS, IS, and US, respectively, and maximum consecutive days without rains during the sampling intervals were about 17 days. Potential (PET) and actual evapotranspiration (AET) decreased with elevation whilst P/PET and P/AET ratios increased with elevation. The P/PET ratio was 1.1, 1.2, and 1.4 for LS, IS, and US, respectively, and the P/AET ratio was $1.41,1.56$, and 1.78 at the same site sequence. Maximum water retention capacity of soil diminished with elevation, with upper site $50 \%$ of lower site. The values observed were influenced by the shallow soil depth considered $(20 \mathrm{~cm})$ that corresponded to the rooting zone but also to the total profile at IS and US. The water budget showed clearly the alternation of humid and dry periods in the soils (Fig. 1). The humid periods
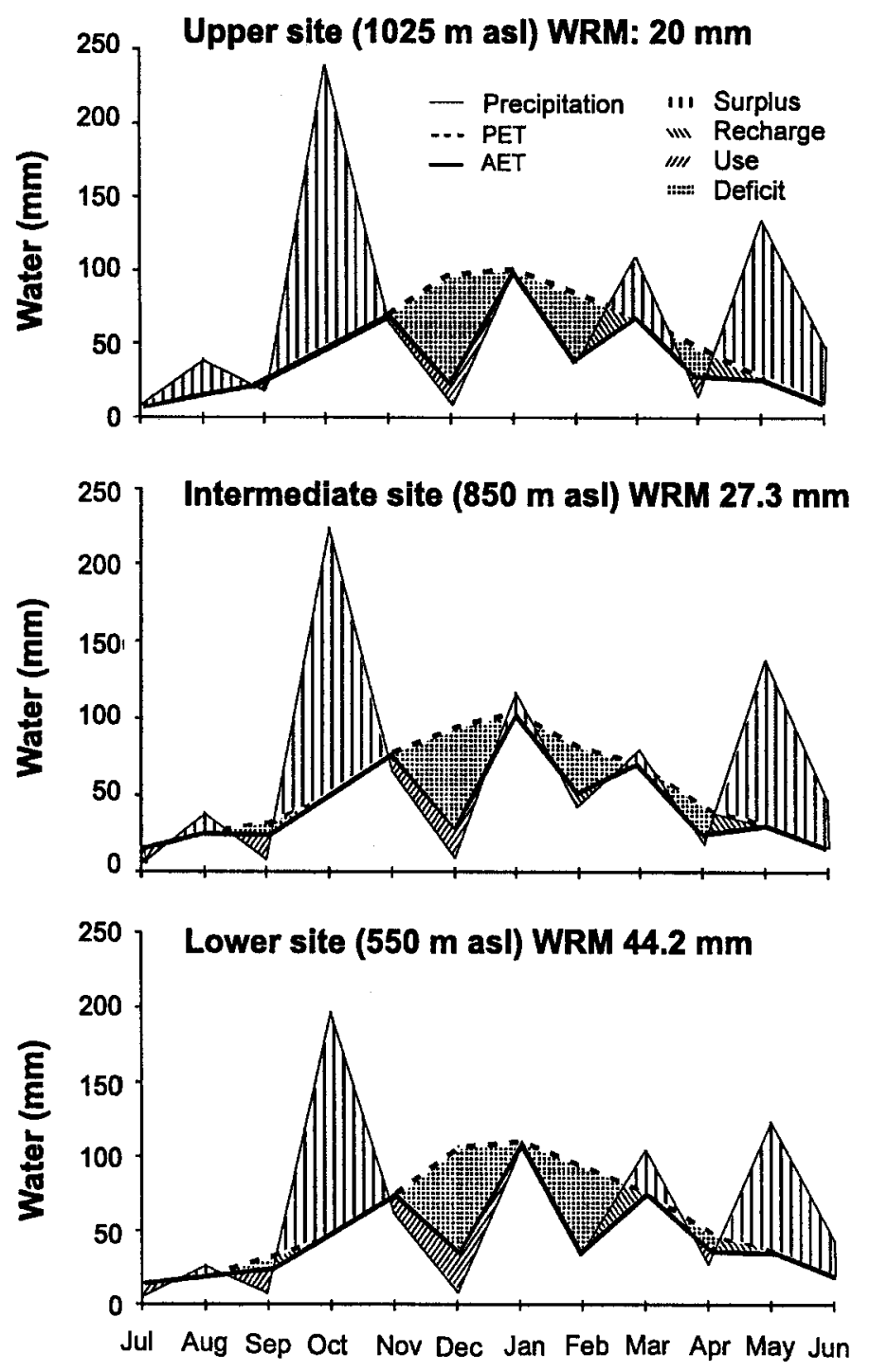

Fig. 1. Thornthwaite's water budgets in grasslands sites located at different altitudes from July 1988 to July 1989. WRM = maximum water retention capacity; PET = potential evapotranspiration; AET = actual evapotranspiration.
Table 2. Physico-chemical characteristics of soils at lower $(550 \mathrm{~m}$ asl $)$, intermediate $(850 \mathrm{~m}$ asl $)$ and upper $(1,025 \mathrm{~m}$ asl) grassland sites. Values are ranges or means for composite samples $(\mathrm{n}=3)$ per site. Different letters indicate significant differences among the 3 sites (Tukey, P $<0.05$ ).

\begin{tabular}{lrrr}
\hline \hline Soil parameter & Lower & Intermediate & Upper \\
\hline Apparent density $\left(\mathrm{g} \mathrm{cm}^{-3}\right)$ & $0.850 \mathrm{a}$ & $0.649 \mathrm{~b}$ & $0.606 \mathrm{~b}$ \\
pH (soil/water 1:1) & 5.4 to $5.9 \mathrm{a}$ & 4.3 to $5.4 \mathrm{a}$ & 4.1 to $5.2 \mathrm{a}$ \\
Texture $(\%)$ & & & \\
$\quad$ Sand & $40.50 \mathrm{~b}$ & $44.40 \mathrm{~b}$ & $58.40 \mathrm{a}$ \\
$\quad$ Silt & $30.70 \mathrm{a}$ & $39.00 \mathrm{a}$ & $28.00 \mathrm{a}$ \\
$\quad$ Clay & $28.90 \mathrm{a}$ & $16.60 \mathrm{~b}$ & $13.60 \mathrm{~b}$ \\
Organic Carbon (\%) & $4.91 \mathrm{a}$ & $5.64 \mathrm{a}$ & $5.90 \mathrm{a}$ \\
Total Nitrogen (\%) & $0.44 \mathrm{a}$ & $0.48 \mathrm{a}$ & $0.55 \mathrm{a}$ \\
C:N ratio & $10.9 \mathrm{a}$ & $11.8 \mathrm{a}$ & $10.9 \mathrm{a}$ \\
P available (ppm) & $12.17 \mathrm{a}$ & $10.50 \mathrm{a}$ & $11.45 \mathrm{a}$ \\
CEC $\left(\mathrm{cmol}_{\mathrm{c}} \mathrm{kg}^{-1}\right)$ & $22.20 \mathrm{a}$ & $22.30 \mathrm{a}$ & $20.15 \mathrm{a}$ \\
Exchangeable bases $\left(\mathrm{cmolc} \mathrm{kg}^{-1}\right)$ & & & $6.19 \mathrm{c}$ \\
$\quad \mathrm{Ca}^{+2}$ & $15.43 \mathrm{a}$ & $9.07 \mathrm{~b}$ & $2.78 \mathrm{c}$ \\
$\mathrm{Mg}^{+2}$ & $6.56 \mathrm{a}$ & $4.31 \mathrm{~b}$ & $0.28 \mathrm{a}$ \\
$\mathrm{Na}^{+}$ & $0.44 \mathrm{a}$ & $0.29 \mathrm{a}$ & $0.43 \mathrm{a}$ \\
$\mathrm{K}^{+}$ & $0.84 \mathrm{a}$ & $0.53 \mathrm{a}$ & 39.0 to $68.3 \mathrm{~b}$ \\
Base saturation $(\%)$ & $90.6 \mathrm{a}$ & 50.0 to $92.2 \mathrm{a}$ &
\end{tabular}

occurred during early spring and fall at all sites. The late-spring water deficit was greater at both IS and US. Summer is clearly the main water consumption period but some recharge also happened; however, most recharge occurred in the autumn. Temperatures favored water consumption during winter at all sites but at US there was a water surplus.

\section{Plant compartments mass}

Total dry matter was greater at the upper site (US) $\left(1,552 \mathrm{~g} \mathrm{~m}^{-2}\right)$ by $20 \%$ more than either of the other 2 sites $\left(1,260 \mathrm{~g} \mathrm{~m}^{-2}\right.$ at IS and $1,225 \mathrm{~g} \mathrm{~m}^{-2}$ at LS). The belowground dry matter increased with altitude and was 52,62 , and $73 \%$ of total dry matter at the lower site (LS), intermediate site (IS), and upper site (US), respectively. Litter 


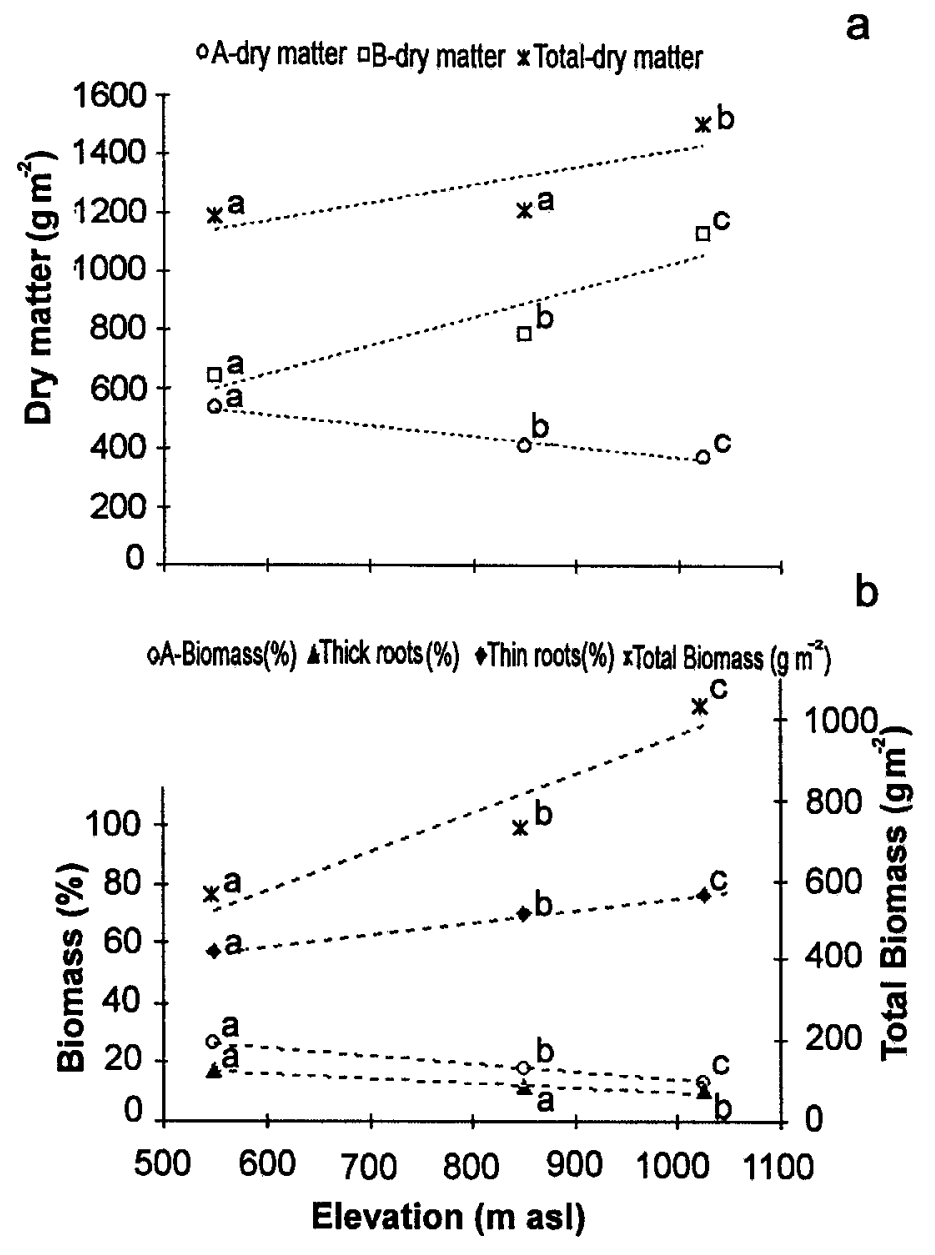

Fig. 2. Annual mean dry weight for different plant compartments in grasslands sites: a) aboveground (A-), belowground (B-) and total dry matter, all in ( $\left.\mathrm{g} \mathrm{m}^{-2}\right)$; b) Aboveground (A-) biomass and live thin and thick roots $(\%)$ with respect to total biomass $\left(\mathrm{g} \mathrm{m}^{-2}\right)$. Different letters indicate significant differences among compartment mean for the 3 sites (Tukey, $P<0.05$ ). Least squares trend lines are indicated with broken line.
$68 \%$ at US; the last 2 were not significantly different.

Normalized proportions of each live compartment with respect to total biomass changed significantly among sites and dates. The green fraction decreased with increasing elevation. Thin roots were the main contributing root compartments to belowground biomass and were responsible for the increase in total live roots with increasing elevation (Fig. 2b). Roots colonized by endophytes forming A-mycorrhizae changed significantly from 40 to $57 \%$ with elevation (Fig. 3). Spores showed a non-significant decreasing trend in the same direction $(20,19$, and 14 , respectively).

Inter-site differences in biomass and dry matter compartments over time resume a distinct balance of functional processes at each site and date, as indicated by statistically significant interactions between location and sampling dates (Fig. 4). The US showed smooth changes in plant compartments over time, whereas both other sites manifested more noticeable stock peaks at different months.

\section{Plant mass and the physical environ- ment}

The multiple regression analyses performed for aboveground dry matter, belowground dry matter, belowground biomass, or above-/belowground biomass ratio with independent variables of monthly mean minimum temperature, monthly available soil water, and monthly actual evapotranspiration were significant (Table 3 ). The regression coefficients of monthly attained only about $3 \%$ of total dry matter at all sites.

Above- and belowground dry matter differed according to location and sampling dates. aboveground dry matter decreased with elevation, while belowground dry matter increased with elevation (Fig. 2a). The rate of decrease in aboveground dry matter was more pronounced $\left(43 \mathrm{~g} \mathrm{~m}^{-2}\right.$ per $100 \mathrm{~m}$ elevation) between LS and IS than between IS and US (21 $\mathrm{g} \mathrm{m}^{-2}$ per $\left.100 \mathrm{~m}\right)$. The rate of increase in belowground dry matter was greater between IS and US $\left(199 \mathrm{~g} \mathrm{~m}^{-2}\right.$ per $\left.100 \mathrm{~m}\right)$ than between LS and IS (47 $\mathrm{g} \mathrm{m}^{-2}$ per $\left.100 \mathrm{~m}\right)$.

Although aboveground dry matter was mainly standing dead and aboveground biomass was similar at all sites, the relative contribution of live tissue increased with elevation $(27,34$, and $36 \%$ at LS, IS, and US, respectively). belowground dry matter was mainly contained in the 0-10 cm soil layer: $71 \%$ at IS, $64 \%$ at LS and

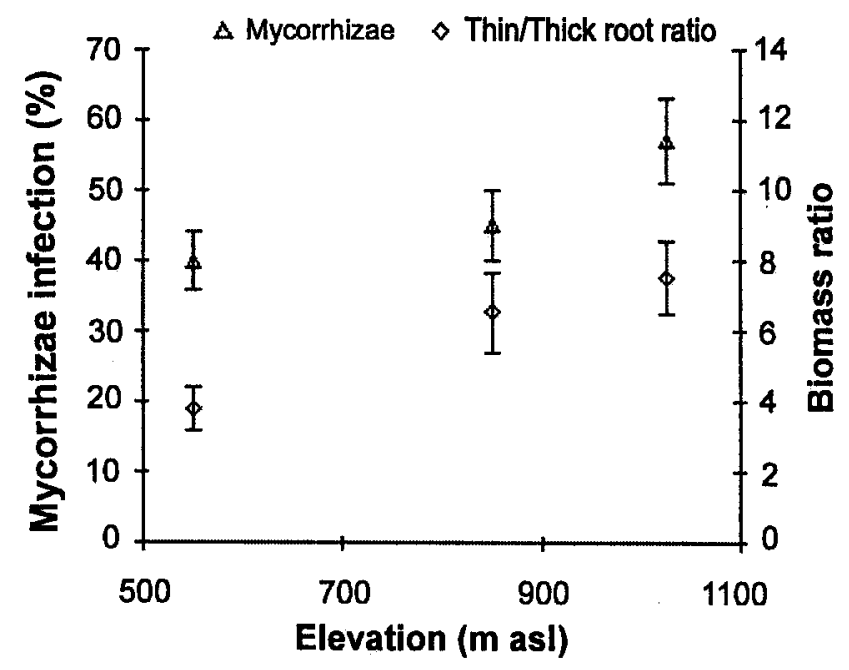

Fig. 3. Thin-/thick live roots ratio and mycorhizae infection (\%) in grasslands sites at different altitudes from July 1988 to July 1989. Vertical lines indicate \pm SE. 
Upper site (1025 m asl)
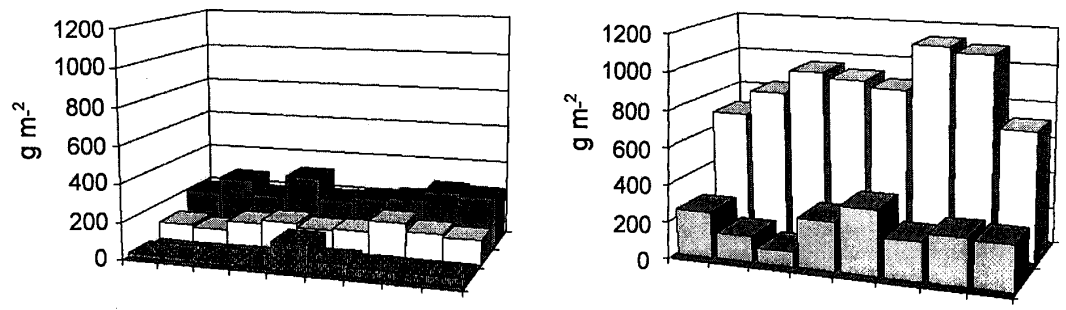

Intermediate site (850 $\mathrm{m}$ asI)
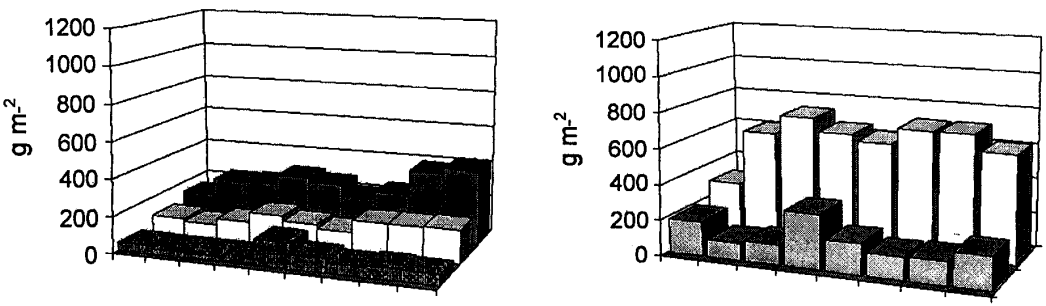

\section{Lower site (550 $\mathrm{m}$ asl)}
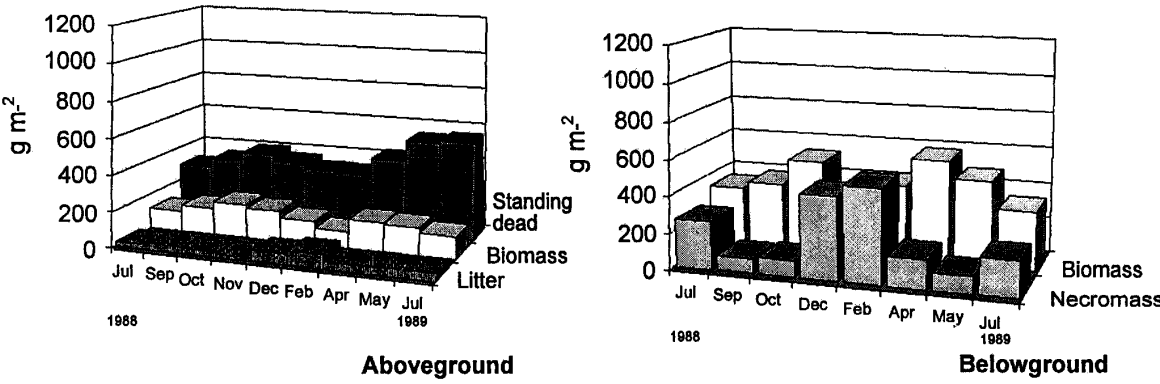

Fig. 4. Above- and belowground dry weight $\left(\mathrm{g} \mathrm{m}^{2}\right)$ for various compartments at 3 grasslands sites located at different altitudes from July 1988 to July 1989.

actual evapotranspiration were non-significant for aboveground dry matter and above/belowground biomass.

The variable site was significantly correlated with all the dependent variables. When these correlations were partialed out by the independent variables of the regression models, no significant correlations were obtained with aboveground dry matter and above/belowground biomass. Monthly available soil water and mean minimum temperature (in that order of importance) mainly explained the differences in dependent variables among sites. The similar range of aboveground biomass at all sites, together with asinchronic intersite variation, appears to explain the absence of correlation with the monthly independent variables (Fig. 4).

\section{Fluxes and turnover rates}

Annual net primary products (NPP) was similar at all sites (ca. 1,131 to $1,280 \mathrm{~g} \mathrm{~m}^{-2}$ ) but the partitioning between above- and belowground tissues changed among sites (41-59\% at lower site, $46-54 \%$ at intermediate site and 33-67\% at upper site, respecA- = aboveground; B- = belowground.

a)

b) tively) (Table 4). Total NPP was bimodal, with one peak during the winter and spring and, another, in summer and autumn. The winter-spring NPP peak was more noticeable at IS and US (73 and $64 \%$ of annual NPP, respectively), since productivity was more evenly distributed at the LS (46\% in winter-spring and $54 \%$ in summerautumn). Reproductive tissues showed a major period of production during spring and lesser production at the beginning of autumn. The spring period showed 2 peaks of reproductive productivity at LS; one at the end of October comprised mainly by the winter exotic annual Vulpia dertonen sis (Allioni) Gola, and another at the beginning of December composed of feathers (Stipa and Piptochaetium). Annual grasses were unimportant at both other sites.

Total senescence was greater and similar at LS and US. The root contribution to total senescence increased with site elevation (61, 64, and 68\%). Litterfall increased slightly with elevation and represented about $10 \%$ of total senescence. Total disappearance of above- and belowground plant parts was greater in both elevational extreme sites (LS and US), where the main contribution came from belowground mass ( 88 and $68 \%$, respectively). Total disappearance at IS was nearly $50 \%$ of both other sites and equally distributed between below- and aboveground tissue (Table 4). As a consequence of differences in litterfall and aboveground disappearance dynamics among sites the LS accumulated a maximum of litter at the end of February, whereas both the other sites had maximum accumulation at the end of December (Fig. 5).

Table 3. a) Multiple regression analysis of dry matter and biomass $\left(\mathrm{g} \mathrm{m}^{-2}\right)$ in grassland sites to water, temperature and evapotranspiration. Only significant equations are given; the non-significant contribution $(P>0.05)$ of individual variables are indicated as $(\mathrm{ns})$. b) Correlation and partial correlation of the site variable with the dependent variables. $W=$ monthly available water $(\mathrm{mm}) ; \mathrm{T}=$ minimum monthly temperature $\left({ }^{\circ} \mathrm{C}\right) ; \mathbf{E T}=$ monthly actual evapotranspiration $(\mathrm{mm})$;

\begin{tabular}{llcrr}
\hline \hline Dependent variables & Equation & Adjusted R & $\mathrm{P}$ & $\mathrm{n}$ \\
\hline Above-ground dry matter & $\mathrm{Y}=275+8 \mathrm{~W}+19 \mathrm{~T}-1.4 \mathrm{ET}^{(\mathrm{ns})}$ & 0.55 & $<0.0001$ & 27 \\
Above-ground biomass & & -0.075 & 0.759 & 27 \\
Below-ground dry matter & $\mathrm{Y}=989-14 \mathrm{~W}-38 \mathrm{~T}+8 \mathrm{ET}$ & 0.35 & $<0.009$ & 24 \\
Below-ground biomass & $\mathrm{Y}=661-13 \mathrm{~W}-64 \mathrm{~T}+14 \mathrm{ET}$ & 0.42 & $<0.002$ & 24 \\
B/A biomass ratio & $\mathrm{Y}=6+0.14 \mathrm{~W}-0.8 \mathrm{~T}-0.2 \mathrm{ET}^{(\mathrm{ns})}$ & 0.54 & $<0.0004$ & 24
\end{tabular}

\begin{tabular}{lccccccccc}
\hline & \multicolumn{1}{c}{ Dependent variable } \\
\cline { 2 - 11 } & \multicolumn{1}{c}{ A-dry matter } & \multicolumn{1}{c}{ B-dry matter } & \multicolumn{1}{c}{ B-biomass } & \multicolumn{2}{c}{ A/B biomass } \\
Site variable & $\mathrm{r}$ & $\mathrm{P}$ & $\mathrm{r}$ & $\mathrm{P}$ & $\mathrm{r}$ & $\mathrm{P}$ & $\mathrm{r}$ & $\mathrm{P}$ \\
Correlation & 0.59 & $<0.001$ & -0.80 & $<0.001$ & -0.77 & $<0.001$ & -0.67 & $<0.001$ \\
Partial correlation & 0.006 & 0.98 & -0.81 & $<0.001$ & -0.84 & $<0.001$ & -0.21 & 0.36 \\
\hline
\end{tabular}


Table 4. Above- and belowground biomass, productivity, senescence, litterfall, disappearance and turnover rates at lower $(550 \mathrm{~m}$ asl $)$, intermediate $(850 \mathrm{~m}$ asl $)$ and upper $(1,025 \mathrm{~m}$ asl $)$ grassland sites. $\mathrm{NPP}=$ net primary productivity.

\begin{tabular}{|c|c|c|c|}
\hline \multirow[t]{2}{*}{ Parameter } & \multicolumn{3}{|c|}{ Site } \\
\hline & Lower & Intermediate & Upper \\
\hline \multicolumn{4}{|l|}{ Biomass $\left(\mathrm{g} \mathrm{m}^{-2}\right)$} \\
\hline Aboveground & $146 \mathrm{a}$ & $138 \mathrm{a}$ & $131 \mathrm{a}$ \\
\hline Belowground & $410 \mathrm{c}$ & $615 b$ & $904 \mathrm{a}$ \\
\hline Total biomass & $556 \mathrm{c}$ & $753 \mathrm{~b}$ & $1035 \mathrm{a}$ \\
\hline \multicolumn{4}{|c|}{ Net primary productivity $\left(\mathrm{g} \mathrm{m}^{-2} \mathrm{y}^{-1}\right)$} \\
\hline Aboveground & 462 & 585 & 378 \\
\hline Belowground & 669 & 695 & 779 \\
\hline Total NPP & 1131 & 1280 & 1157 \\
\hline \multicolumn{4}{|l|}{ Senescence $\left(\mathrm{g} \mathrm{m}^{-2} \mathrm{y}^{-1}\right)$} \\
\hline Aboveground & 434 & 374 & 319 \\
\hline Belowground & 685 & 368 & 691 \\
\hline Total senescence & 1119 & 742 & 1010 \\
\hline Litterfall $\left(\mathrm{g} \mathrm{m}^{-2} \mathrm{y}^{-1}\right)$ & 107 & 210 & 232 \\
\hline \multicolumn{4}{|l|}{ Disappearance $\left(\mathrm{g} \mathrm{m}^{-2} \mathrm{y}^{-1}\right)$} \\
\hline Aboveground & 103 & 200 & 210 \\
\hline Belowground & 756 & 275 & 731 \\
\hline Total disappearance & 859 & 475 & 941 \\
\hline \multicolumn{4}{|c|}{ Dry matter turnover rate $\left(\mathrm{y}^{-1}\right)$} \\
\hline Aboveground & 0.9 & 1.4 & 1.0 \\
\hline Belowground & 1.0 & 0.9 & 0.7 \\
\hline \multicolumn{4}{|l|}{ Biomass turnover rate $\left(\mathrm{y}^{-1}\right)$} \\
\hline Aboveground & 3.2 & 4.2 & 2.9 \\
\hline Belowground & 1.6 & 1.1 & 0.9 \\
\hline
\end{tabular}

Turnover rates for aboveground biomass were higher than for belowground biomass at all sites (Table 4). The US presented the slowest turnover rates of live tissues.

\section{Discussion}

\section{Soils and water budget}

The reduction of the mineral colloidal fraction with elevation was buffered by the high content of soil organic matter and this explains similar CEC's at all sites. The lower base saturation and $\mathrm{pH}$ at higher elevation indicated that even though these were fertile soils, exchangeable nutrients were more limited at higher elevations. The relief heterogeneity and increased precipitation and runoff at the higher elevation site also influenced soil characteristics and helped to explain the increased variation in soil parameters. Thornthwaite's water budgets, estimation of runoff, and actual evapotranspiration gave comparable results to those empirically derived during the same period from the 158 ha watershed where the research sites were located (Bianchi and Dascanio pers. com.). The runoff at upper site and intermediate site were 44 and $36 \%$ of precipitation, respectively, vs $39-40 \%$ from the entire watershed above $550 \mathrm{~m}$. Thornthwaite's water budget calculation did not include the wind effect in the evapotranspiration estimation. Although the upper slopes and increased with elevation. Sims et al. (1978), in their studies of North American grasslands, indicated that it was not possible to assume a general relationship between aridity and high belowground/aboveground ratios. This ratio could be more related to life forms (NoyMeir 1973, Liang et al. 1989) or temperature regime than with aridity (Noy-Meir 1973, Sims et al. 1978).

In Sierra de la Ventana altitudinal differences in belowground/aboveground biomass ratio could not be related to aridity as indicated by general climate and P/AET and $\mathrm{P} / \mathrm{PET}$ ratios at each site. Lower soil water retention with elevation probably played an important role in magnifying the temporary water shortage derived from periods with several consecutive days without rain.

The relationship of the belowground/aboveground biomass ratio with life form has been recognized in tussock and non-tussock grasses of these sierra grasslands (Barrera and Frangi 1994); however, within each life form the ratio increased mainly as temperature decreased.

The belowground/aboveground dry matter ratio also increased with elevation. This ratio was 1.2 for the lower, 1.8 for the intermediate, and 3.0 for the upper site. These values are within the total range of physiognomic and altitudinal grassland types of Sierra de la Ventana, where the ratio varies between 0.13 (at $350 \mathrm{~m}$ with tussocks) to 4 (in the crests at 1,100 m elevation) (Barrera and Frangi 1994).

Körner and Renhardt (1987) have indicated for the Central Alps that the increased dicotyledonous herb belowground dry matter fraction at higher elevation resulted from shoot reductions and a proportional increase in thin roots. An extended thin root system at higher elevations could be a functional substitute for mycorrhizae that are more common at low elevations. Although mycorrhizal colonization directly with increases in soil temperature (Azcón-Aguilar et al. 1984), the degree of fungal colonization forming Amycorrhizae is also dependent on root system morphology, since thin roots are more susceptible to colonization (Hetrick et al. 1988, Reinhardt and Miller 1990). In sierra grasslands under a milder climate than the alpine, our results suggested a greater mycorrhizal activity coincidently with more thin roots rather than with temperature, as temperature decreased with elevation. belowground biomass and mycorrhizae abundance indicated greater soil volume 


\section{Aboveground}
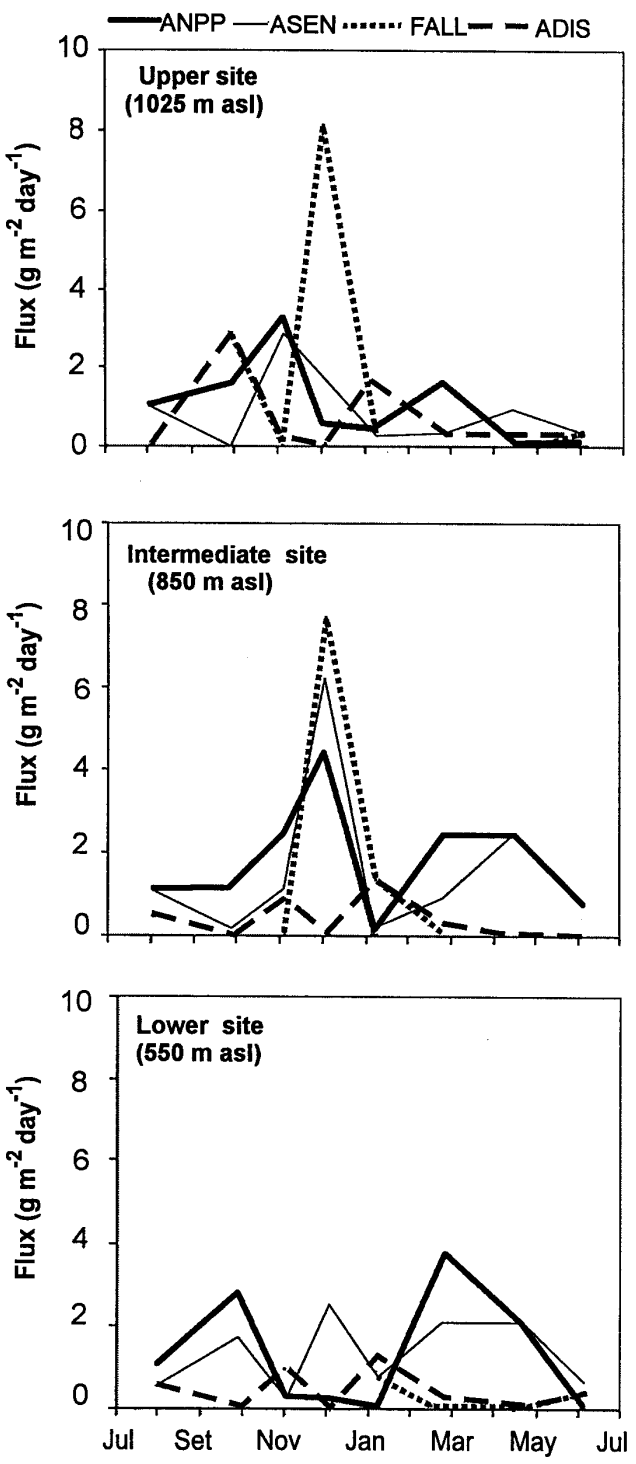

\section{Belowground}
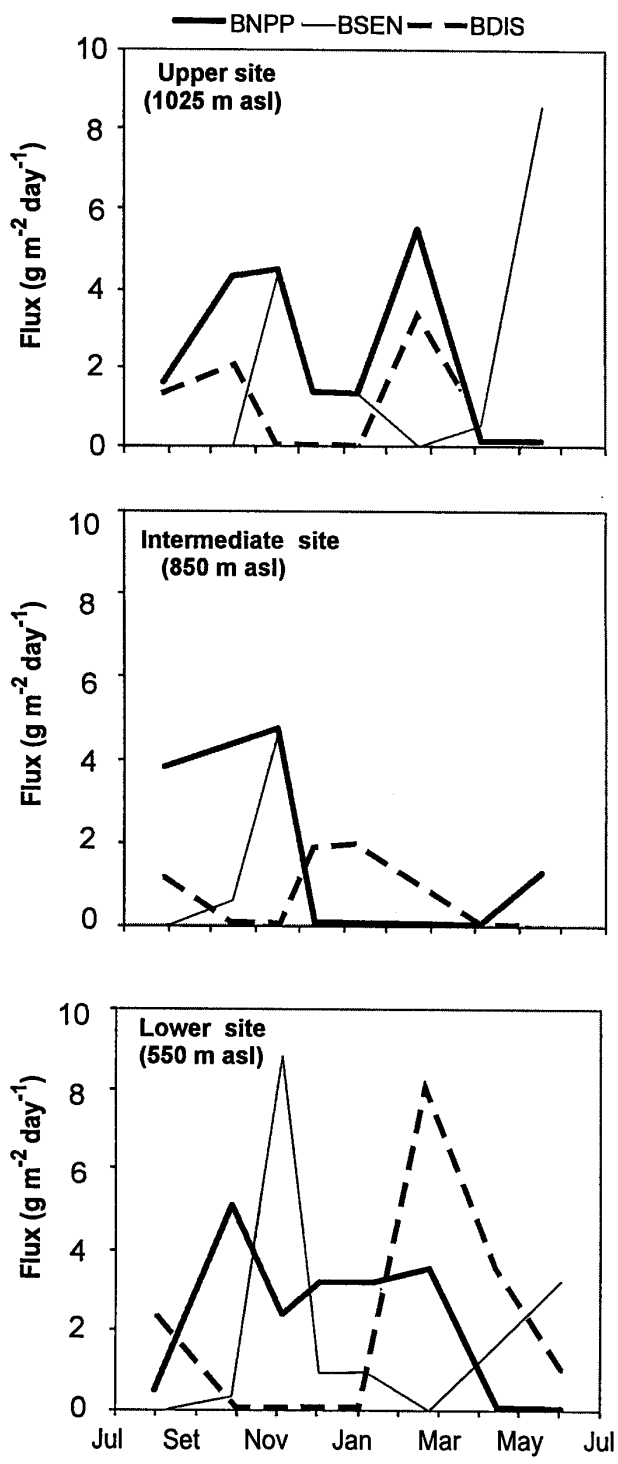

Fig. 5. Aboveground fluxes: net primary productivity (ANPP), senescence (ASEN), litterfall (FALL) and disappearance (ADIS); and belowground fluxes: net primary productivity (BNPP), senescence (BSEN) and disappearance (BDIS) in grassland sites at different altitudes from July, 1988 to July, 1989.

occupation when availability of soil resources decreased. Chapin (1991) has proposed that a more intense occupation of soil volume is a general response of plants to stress when resources are limiting.

\section{Dry matter dynamics and fluxes}

The 3 sites showed similar trends in dry matter and litter dynamics throughout the year. aboveground compartments and live roots increased during spring and early autumn. Root growth during winter-spring preceded aboveground biomass increases.
Summer and winter were the seasons when necromass increased and biomass decreased. The aboveground dry matter increased during the spring as temperature and rainfall increased, but maximum stocks were found at different dates varying with elevation. The spring peak in growth occurred earlier in the lower grassland. Temperatures more favorable to aboveground growth were attained later at higher altitudes.

We found differences among altitudinal sites in the length of quiescence of vegetation. The cold period was more extended in the upper grassland than in the lower one; in the intermediate grassland the rest period was during summer drought, not in winter. At the upper site, summer was not a true rest period but one with reduced production rates (Fig. 5). This behavior was consistent with seasonal changes in temperature and evaporative capacity that have been reported for this eastern slope (Kristensen and Frangi 1995).

Roots in the upper soil layer were the most dynamic component of belowground dry matter. The lesser variability in the deeper root mass has been attributed to the more constant thermal and hydric conditions of this layer relative to the surface layer (Dahlman and Kucera 1965, Fernández and Caldwell 1975, Ares 1976). Although live thin roots increased during favorable thermic and hydric periods, periods of high senescence followed during dry consecutive days.

The ecological differences among sites were not expressed by total net primary production (NPP), which was similar at all sites, but by its partitioning in space and time. The higher elevation grassland community invested a higher proportion of annual NPP in roots, independent of season. The allocation pattern changed seasonally at the other 2-sites. At the end of summer and beginning of autumn, which was more humid than in spring, above ground net primary production (ANPP) showed a decreasing trend with increase in altitude. The proportion of NPP allocated to photosynthetic tissues increased from the summits to the piedmont.

\section{Turnover rates}

Faster turnover rates for aboveground compartments than for belowground compartments have been reported in other grassland systems (Kucera et al. 1967, Sims and Singh 1978, Aerts et al. 1989, Soriano 1992). The differences in photosyntate partitioning and biomass distribution are shown by the different turnover rates (productivity/biomass) of aboveground and belowground live tissues at each site. Since mean aboveground biomass and total net productivity were similar at all sites, the lower turnover rate of 


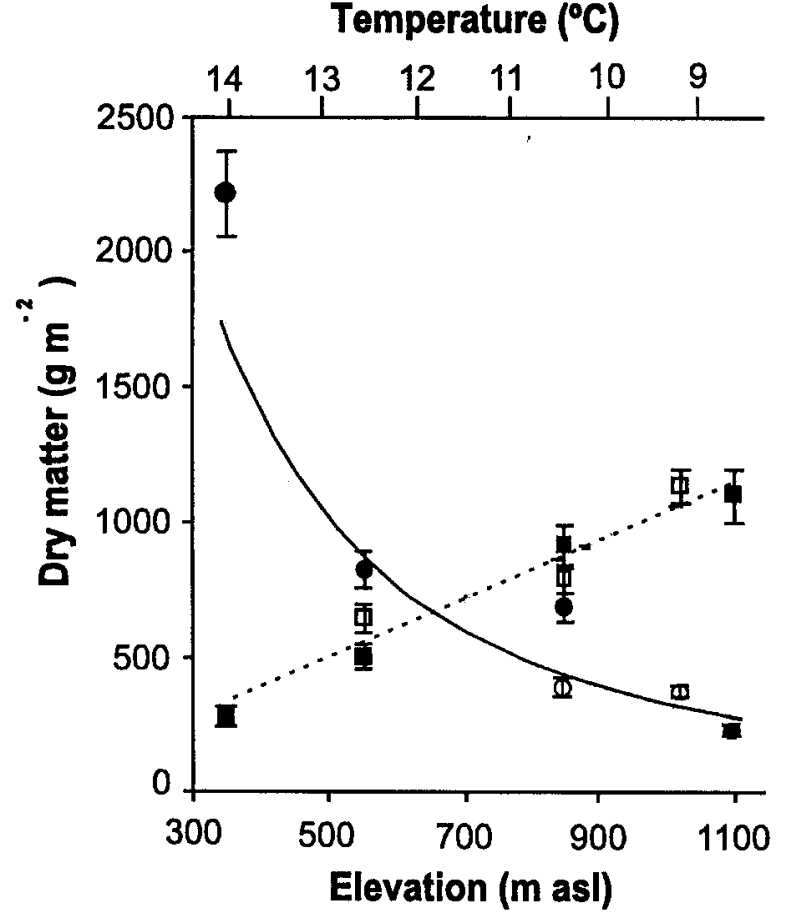

Fig. 6. Above (A-) (circle) and belowground (B-) (square) dry matter in sites located within the elevational range from 350 to 1,100 m asl. Sites from Barrera and Frangi (1994) (solid symbols) include the lowland tussock grasslands and high sierra meadows at the extremes of the gradient. Open symbols indicate data from our sites. Vertical lines indicate \pm SE. Estimates of sites normal annual mean temperature (calculated with standard weather reports data for 1961-1970 period and $0.7^{\circ} \mathrm{C}$ thermal gradient) is indicated as a second $\mathrm{x}$ axis.

aboveground biomass at higher elevation reflected the greater allocation of photosyntates to roots. In contrast, the lower turnover of roots at higher elevations indicated that although belowground productivity is greater, root replacement is slower because of its higher biomass compared to lower grasslands. The higher turnover rates and lower biomass of roots at the lower site suggested that more fertile soils were faster exploited during the humid periods, prolonged because of more loamy textures, while periods with scarce water availability may have stimulated root replacement. A texture that holds more water facilitates this strategy for sustaining a similar aboveground mass of live tissue to produce more aboveground tissues. Probably high temperatures and evapotranspiration at lower sierra slopes trigger a higher turnover rate of aboveground live tissue. As a consequence of higher productivity and senescence and lower disappearance of aboveground tissues, standing dead material accumulated more at the lower site and turnover rate of aboveground dry matter was slower. A similar annual absolute mass senescence and disappearance of roots at both extremes of the elevational gradient indicated a higher belowground senescence rate and decomposition rate per mass unit of root, under soil conditions that prevailed at the lower site. Inversely, the markedly greater annual absolute aboveground disappearance suggested that aboveground disappearance rate per unit of aboveground dry mass was higher at the upper site, probably enhanced by higher humidity and lower saturation deficits.

\section{Comparison with other temperate grasslands}

aboveground dry matter and net primary production (NPP) values for these sierra grasslands fell within the range reported for USA ungrazed temperate grasslands (Sims et al. 1978, Sims and Singh 1978). belowground dry matter was lower than in USA comparable mixed-grass and tallgrass prairie sites. Although NPP of sierra grasslands was near the lower value of mixed-grass prairie, the above ground net primary production (ANPP) at sierra sites was higher than at USA sites reported by Sims and Singh (1978). Consequently, there was greater BNPP/NPP ratio at USA than at Pampa sites despite the partial overlap in the quotient range (61 to $75 \%$ vs 54 to $67 \%$, respectively). Since sites like Hays and Osage (Sims et al. 1978) were the most comparable to Sierra de la Ventana in latitude, mean temperature, precipitation, and vegetation parameters, we suggest that the harder seasonality (226 to 272 days length of thermal potential growth season, respectively) in the Northern Hemisphere compared to our sites, located in more oceanic climates (more than 300 days of estimated length of thermal potential growth season), influenced the structural and functional differences.

With respect to productivity, Laurenroth (1979) considered that the most productive grassland sites of the world were those with around $800 \mathrm{~mm}$ annual precipitation and a mean temperature $>15^{\circ} \mathrm{C}$. His grassland group 6 included a wide set of sites characterized by a lack of a significant drought period at any time of the year and an ANPP in the range of $160-1,387 \mathrm{~g} \mathrm{~m}^{-2}$ year ${ }^{-1}\left(\right.$ mean $=525 \mathrm{~g} \mathrm{~m}^{-2}$ year $\left.^{-1}\right)$. The ANPP of the Sierra de la Ventana grasslands were $\pm 12 \%$ to $-28 \%$ of the grassland group 6 mean. The main difference appeared for the higher elevation site, where productivity was composed mainly of belowground tissues. Gómez and Gallopín (1991) modeled the productivity of Latin American biomes and the range for Pampean grasslands was 400-600 $\mathrm{g} \mathrm{m}^{-2}$ year $^{-1}$. The sierra grasslands ANPP (378 to $585 \mathrm{~g} \mathrm{~m}^{-2}$ year $^{-1}$ ) fit within that range, as did those from Pampa lowland ungrazed sites like Salado River basin grasslands with $532 \mathrm{~g} \mathrm{~m}^{-2}$ year ${ }^{-1}$ (Sala et al. 1981) and La Pampa grasslands with $410 \mathrm{~g} \mathrm{~m}^{-2}$ year $^{-1}$ (de Wysiecki 1993). The greater aboveground productivity $\left(700 \mathrm{~g} \mathrm{~m}^{-2}\right.$ year $\left.^{-1}\right)$ estimated for the lower site a decade before (Frangi et al. 1980 a) suggested that annual productivity variation in the sierra grasslands is important.

\section{Conclusions}

The similar mean annual aboveground biomass at all sierra grassland sites suggested that a common threshold carrying capacity of green tissues had been attained. As total production was also similar among 3 elevational sites this suggested that photosynthetic efficiency was equivalent at all sites. The differences among sites observed in belowground biomass and proportion of fine roots that were linked to temperature and soil water holding capacity appeared to reflect an adaptive trend for improved water and nutrient absorption with eleva- 
tion. As there were no differences in aboveground biomass, grass life forms or NPP among sites, and evapotranspiration could be similar at all sites, the belowground biomass is probably satisfying a similar water demand. Because of a lower water holding capacity with elevation, a more intense occupation of soil is necessary to accomplish water absorption under colder conditions.

\section{Literature Cited}

Aerts, R., F. Berendse, N.M. Klerk, and C. Bakker. 1989. Root production and root turnover in two dominant species of wet heathlands. Oecologia (Berlin) 81:374-378.

Ares, J. 1976. Dynamics of the root system of blue grama. J. Range Manage. 29:208-213.

Andreis, R., A.M. Iñiguez, L.L. Lluch and S. Rodriguez. 1989. Cuenca paleozoica de Ventania, Sierras Australes, Provincia de Buenos Aires, p. 265-298. In: Chebli, G. and L. Spalletti (eds.) Cuencas Sedimentarias Argentinas. Serie Correlación Geológica 6. San Miguel de Tucumán (Argentina).

Azcón-Aguilar, C., J.M. Barea and B. Roldán-Fajardo. 1984. Avances recientes en el estudio de las micorrizas VA. II. Factores que afectan su formación y función y aplicaciones prácticas en agricultura. Anales Edafología y Agrobiología (Spain) 42:943-958.

Barrera, M.D. 1991. Ecología de las comunidades con arbustos de la Sierra de la Ventana. Ph.D. Thesis, Univ. Nacional La Plata, La Plata (Argentina).

Barrera, M.D. and J.L. Frangi. 1994. Estructura de la biomasa de pastizales en Sierra de la Ventana (Buenos Aires, Argentina). Rev. Museo La Plata (NS) 14:243-262.

Barrera, M.D. and J.L. Frangi. 1996. Estructura poblacional de los arbustos Eupatorium buniifolium y Discaria americana con relación a la pedregosidad del suelo y el pastoreo en la Sierra de la Ventana, Buenos Aires, Argentina. Rev. Facultad Agronomía, La Plata (Argentina) 101:113-125.

Böhm, W. 1979. Methods of studying root systems. Ecological Studies 33. SpringerVerlag, Berlín.

Burgos, J.J. 1968. El clima de la Provincia de Buenos Aires en relación con la vegetación natural y el suelo, p. 34-97. In: A.L. Cabrera (ed.) Flora de la Provincia de Buenos Aires. Colección Científica INTA 4(1). Buenos Aires.

Cabrera, A.L. (ed.) 1963. Flora de la Provincia de Buenos Aires. Parte VI Compuestas. Colección Científica INTA, 4. Buenos Aires

Cabrera, A.L. 1968. La vegetación de la Provincia de Buenos Aires, p. 101-126. In: A.L. Cabrera (ed.), Flora de la Provincia de Buenos Aires. Colección Científica INTA, 4(1).Buenos Aires.
Cabrera, A.L. (ed.) 1970. Flora de la Provincia de Buenos Aires. Parte II Gramíneas. Colección Científica INTA, 4. Buenos Aires

Cappanini, D., C.O. Scoppa, and J.R. Vargas Gil. 1971. Suelos de las Sierras Australes de la Provincia de Buenos Aires. p. 203-234. In: Reunión Geología Sierras Australes. Comisión Investigaciones Científicas, La Plata (Argentina).

Chapin, F.S III. 1991. Integrated Responses of Plants to Stress. BioScience 41:29-36.

Dahlman, R.C. and C.L. Kucera. 1965. Root productivity and turnover in native prairie. Ecol. 46:84-89.

de la Sota, E.R. 1967. Composición, origen y vinculaciones de la flora pteridológica de las Sierras de Buenos Aires (Argentina). Bull. Soc. Argentina Botánica 11:105-128.

de Wysiecki, M.L. 1993. Productividad primaria neta aérea de un pastizal natural de la provincia de La Pampa, Argentina. Rev. Facultad Agronomía, La Plata (Argentina) 69:23-29.

Duchaufour, P. 1970. Precis de Pedologie. Masson et Cie. Paris.

Fernández, O.A. and M.N. Caldwell. 1975. Phenology and dynamics of root growth of three cool semi-desert shrubs under field conditions. J. Ecol. 63:703-714.

Frangi, J.L. and O. Bottino. 1995. Las comunidades vegetales de la Sierra de la Ventana, Provincia de Buenos Aires, Argentina. Rev. Facultad Agronomía, La Plata (Argentina) 71:93-133.

Frangi, J.L., N.E. Sánchez, M.G. Ronco, G. Rovetta, and R. Vicari. 1980 a. Dinámica de la biomasa y productividad primaria aérea neta de un pastizal de "flechillas" de Sierra de la Ventana (Buenos Aires, Argentina). Bull. Soc. Argentina Botánica 19:203-228.

Frangi, J.L., M.G. Ronco, N.E. Sánchez, G. Rovetta, and R. Vicari. 1980 b. Efecto del fuego sobre la composición y dinámica de la biomasa de un pastizal de Sierra de la Ventana (Buenos Aires, Argentina). Darwiniana (Argentina) 22:565-585.

Frissel, M.J. 1981. The definition of residence time in ecological models, p. 117-122. In: F.E. Clark and T. Roswall (eds.) Terrestrial Nitrogen Cycles. Ecol. Bull.33. Stockholm.

Gerdemann, J.W. and T.H. Nicolson. 1963. Spores of mycorrhizal endogone species extracted from soil by wet sieving and decanting. Trans. Brit. Mycol. Soc. 46:235-244.

Giovannetti, M. and B. Mosse. 1980. An evaluation of techniques for measuring vesiculararbuscular mycorrhizae infection in roots. New Phytol. 84:489-500.

Gómez, I. A. and G.C. Gallopín. 1991. Estimación de la Productividad primaria neta de ecosistemas del mundo en relación a factores ambientales. Ecología Austral (Argentina) 1:24-40.

Harrington, H. 1947. Hojas geológicas $33 \mathrm{~m} \mathrm{y}$ $34 \mathrm{~m}$, Sierras de Curamalal y de la Ventana, Provincia de Buenos Aires. Serv. Nac. Minero Geológico. Bull.61. Buenos Aires.
Hetrick, B.A., D.G. Kitt and G.T. Wilson. 1988. Mycorrhizal dependence and growth habit of warm season and cool-season tallgrass prairie plants. Can.J.Bot. 66:1376-1380.

Hunter, A.H. 1982. International soil fertility evaluation and improvement: Laboratory procedures. In: Department of Soil Science (ed.) North Carolina State University. Raleigh, N.C.

Hurlbert, S.H. 1984. Pseudoreplication and the design of ecological field experiments. Ecol. Monogr. 54:187-211.

Körner, Ch. and V. Renhardt. 1987. Dry matter partitioning and root length/leaf area ratios in herbaceous perennial plants with diverse altitudinal distribution. Oecologia (Berlin) 74:411-418.

Kristensen, M.J. and J.L. Frangi. 1995. Mesoclimas de pastizales de la Sierra de la Ventana. Ecología Austral (Argentina) 5:55-64.

Kucera, C.L., R.C. Dahlman, and M.R. Koelling. 1967. Total net productivity and turnover on an energy basis for tallgrass prairie. Ecol. 48:536-541

Lauenroth, W.K. 1979. Grassland Primary Production: North American grassland in perspective, p. 1-24. In: N.R. French (ed.) Perspectives in grassland ecology. Ecol. Studies 32. Springer Verlag. Berlín.

Liang, Y.M., D.L. Hazlett, and W.K. Lauenroth. 1989. Biomass dynamics and water use efficiencies of five plant communities in the shortgrass steppe. Oecologia (Berlin) 80:148-153.

McClaugherty, C.A., J.D. Aber, and J.R. Melillo. 1982. The role of fine roots in the organic matter and nitrogen budgets of two forested ecosystems. Ecol. 64:1481-1490.

Milner, C. and R. E. Hughes. 1970. Methods for the measurement of the primary production of grasslands. IBP Handb. 6. Blackwell Sci. Publications, Oxford and Edinburgh.

Noy-Meir, I. 1973. Desert Ecosystems: Environment and Producers. Annu. Rev. Ecol. Syst. 4:25-51.

Page, L. A. 1982. Methods of soil analysis. Part 2, $\mathrm{N}^{\circ}$ 9. Amer. Soc. of Agron., Madison, Wis.

Pérez, C. 1996. Productividad en pastizales serranos a lo largo del gradiente altitudinal. Ph.D. Thesis. Univ. Nacional La Plata. La Plata, Argentina.

Phillips, J.M. and D.S. Hayman. 1970. Improved procedures for clearing roots and staining parasitic and VA-mycorrhizal fungi for rapid assessment of infection. Trans. Brit. Mycol. Soc. 55:158-161.

Piper, J.K. 1989. Distribution of dry mass between shoot and root in nine understory species. Amer. Midland Natur. 122:114-119.

Reinhardt, D.R. and R.M. Miller. 1990. Size classes of root diameter and mycorrhizal fungal colonization in two temperate grassland communities. New Phytol. 116:129-136.

Ricci, S. 1992. Relaciones entre la vegetación y la actividad agropecuaria en el área de Sierra de la Ventana. Ph.D. Thesis, Univ. Nacional La Plata, La Plata (Argentina). 
Sala, O.E., V.A. Deregibus, T. Schlichter, and H. Alippe. 1981. Productivity dynamic of a native temperate grassland in Argentina. J. Range Manage. 34:48-51.

Sims, P.L. and S. Singh. 1978. The structure and function of ten western North American grasslands (III). J. Ecol. 66:573-597.

Sims, P.L., J.S. Singh, and W.K. Lauenroth. 1978. The structure and function of ten western North American grasslands (I). J. Ecol. 66:251-285.

SMN. 1981. Estadística Climatológica 19611970. Serie B, 35. Fuerza Aérea Argentina, Servicio Meteorológico Nacional. Buenos Aires.

Soil Survey Staff. 1992. Keys to Soil Taxonomy. Agency Int. Develop-USDA Soil Conservation Service, SMSS Technical Monograph 19. Pocahontas Press Inc, Blacksburg, Virg.
Sokal, R.R. and F.J. Rohlf. 1969. Biometry. The principles and practice of statistics in biological research. Freeman and Co., San Francisco, Calif.

Soriano, A. 1992. Rio de la Plata Grasslands, p. 367-407. In: R.T. Coupland (ed.) Natural grasslands: Introduction and Western Hemisphere. Ecosystems of the World 8 A Elsevier. Amsterdam.

Suero, T. 1972. Compilación geológica de las Sierras Australes de la Provincia de Buenos Aires. LEMIT, La Plata (Argentina) Ser.II(116)

Tabatabai, A.M. and J.M. Bremner. 1991. Automated Instruments for Determination of total Carbon, Nitrogen and Sulfur in Soils by Combustion Techniques, p. 261-286. In: Soil Analysis, Modern Instrumental Techniques, 2nd Ed. Marcel Dekker. Inc. New York, N.Y.
Thornthwaite, C.W. 1948. An approach toward a rational classification of climate. The Geograph. Review 38:55-94.

Thornthwaite, C.W. and J.R. Mather. 1957. Instructions and tables for computing potential evapotranspiration and the water balance. Publ. Climatol. 10(3), Laboratory of Climatology, Drexel Institute of Technology, Centerton, N.J.

Vargas Gil, J.R. and C.O. Scoppa. 1973. Suelos de las Sierras de la Provincia de Buenos Aires. Rev. Investig. Agropecuarias (Argentina), Ser. 3 Clima y Suelo 10:57-79.

Vervoorst, F. 1967. La vegetación de la República Argentina. VII. Las comunidades vegetales de la depresión del Salado (Provincia de Buenos Aires). INTA, Serie Fitogeog. 7. Buenos Aires.

Von Gosen, W.W., W. Buggisch and L.V. Dimieri. 1990. Structural and metamorphic evolution of the Sierras Australes (Buenos Aires Province, Argentina). Geologische Runtschau 79:797-821. 